\title{
SCRIBAL PRACTICES IN THE ARAMAIC LITERARY TEXTS FROM QUMRAN
}

\author{
Florentino García Martínez
}

When Maxine Grossman invited me to take part in the meeting of the Society of Biblical Literature held in Boston in $2008^{1}$ she specified that she was interested in

how understanding of the Dead Sea Scrolls as material objects fits into a larger understanding of the history and social realities associated with the communities that composed, copied, and transmitted them.

I promised her that I would look at the scribal practices and approaches as reflected in Qumran's literary Aramaic texts to try to find the beginning of an answer to her questions. Since the first draft of this paper was read and discussed at the meeting, it has been a real pleasure to rework it into this small contribution dedicated to my friend and colleague of many years, Jan Bremmer, from whom I have learned so much about Greek mythology and early Christian texts. In particular, he taught me much about critically extracting nuggets of knowledge on the historical realities behind the texts themselves and behind their transmission in different cultural milieus. In this article much of the style of the oral presentation is retained.

While preparing my talk, I was rather confident that I could fulfil my task without much effort. In the standard treatment of the scribal practices and approaches to the Dead Sea Scrolls, where great attention is given to the two basic categories of literary and documentary texts, the differences (if any) between the scribal practices reflected in literary texts written in Hebrew and those written in Aramaic are not specifically dealt with, but I assumed I could discover some peculiarities in the Aramaic texts. ${ }^{2}$ I expected that a careful look at the material aspects of the Aramaic

${ }^{1}$ This was a joint meeting of the Qumran Section and the Social History of Formative Christianity and Judaism Section of the SBL. Apart from its convenor Maxine Grossmann I thank the two other participants, Emanuel Tov and Robert A. Kraft, and the respondent Roger Bagnall, for their observations.

${ }^{2}$ I am referring, of course, to the magisterial treatment by E. Tov, Scribal Practices and Approaches Reflected in the Texts from the Judean Desert (Leiden: Brill, 2004); this 
scrolls would help us to define their characteristics, in contrast to those in Hebrew, and in this way help us to understand better how they relate to the group (or groups) that brought together the collection as a whole.

The Aramaic literary texts form a minority, but a sizeable one, within the whole Qumran collection: about 120 manuscripts, of which some eighty (belonging to 29 different compositions) have enough text preserved to allow them to be treated in a meaningful way. ${ }^{3}$ These groups of Aramaic literary texts have recently and increasingly been considered as forming a coherent whole and being worthy, as such, of a detailed study. ${ }^{4}$ But the basic questions about 1) the specificity of these texts within the collection, 2) their possible origin at Qumran, and 3) their function within the collection as a whole, are still unresolved. Perhaps a look at the scribal practices reflected in the manuscripts of the Aramaic compositions could help us somehow to answer these questions.

But, after carrying out the required research, looking for many hours at the photographs of the Aramaic texts and comparing them with the Hebrew ones, I understood clearly why Emanuel Tov has not dealt specifically with the texts written in Aramaic, but put them in the same category as the Hebrew texts. The reason is very simple: there are no differences in the scribal practices among the two sorts of texts. Concerning the 'Writing and Writing Materials, ${ }^{5}$ the 'Technical Aspects of Scroll Writing,' and the 'Writing Practices,', the texts written in Hebrew and those written in Aramaic offer identical profiles. It is thus totally comprehensible that Tov deals with both sorts of texts together, since they cannot be differentiated by scribal practices. Nevertheless, could we still learn something from the scribal practices so similar in the two sorts of texts? I think we can, and this identity may help us to understand the specificity

is a summa of observations and tables, where every possible aspect of scribal practices is noted, analyzed, and commented upon.

${ }^{3}$ For a complete listing, see the "List of the Texts from the Judaean Desert", in E. Tov et al., The Texts from the Judaean Desert (Oxford: Clarendon, 2002), 27-114. The latest volume with Aramaic texts has been recently published by E. Puech, Qumran Grotte 4.XXVII: (4Q550-4Q583). Textes Araméens, deuxième partie (Oxford: Clarendon, 2008).

${ }^{4}$ This group of texts, as such, has been edited independently, for example, by K. Bayer, Die aramäischen Texte vom Toten Meer, 2 vols. (Göttingen: Vandenhoeck \& Ruprecht, 1984-2003) and by U. Schatter-Rieser, Textes araméens de la mer Morte (Brussels: Safran, 2005).

5 Tov, Scribal Practices, 32-55.

6 Tov, Scribal Practices, 57-129.

7 Tov, Scribal Practices, 131-235. 
of the Aramaic texts within the collection, their possible Qumran origins, and their function within the collection, and therefore to increase our

understanding of the history and social realities associated with the communities that composed, copied, and transmitted them.

\section{Specificity of the Texts within the Collection}

In Tov's book, the Aramaic texts are not considered as a specific group. In the chapter on 'Special Scribal Characteristic of Some Group of Texts,' the Aramaic texts are not specifically dealt with. In this chapter Tov analyzes as different groups: the 'biblical texts', the tefillin and Mezuzot, the pesharim (which can be considered as a group only on the basis of the contents), together with the texts written in Paleo-Hebrew and the texts written in Cryptic Scripts (which can be considered as a group only on the basis of their script), the texts written on papyrus (grouped on the basis of the materials used for writing), and the texts written in Greek (considered as a group on the basis of the language). If not for other reasons, the Aramaic texts should be considered as a group on the same basis as the Greek texts: their language differs from the language in which the majority of the manuscripts are written, Hebrew. But I think there are more reasons to consider them as a coherent whole with a particular language, style, and content, as was done in the meeting dedicated to them in July 2008 in Aix-en-Provence.

In fact, at least two scholars (Devorah Dimant and Eibert Tigchelaar) have recently focused on the specificity of the Aramaic texts as a group within the collection, and have tried to discover different clusters of compositions among them. ${ }^{9}$ In her contribution to my Festschrift Flores Florentino, Devorah Dimant published a groundbreaking article with the title "The Qumran Aramaic Texts and the Qumran Community". ${ }^{10}$ In

\footnotetext{
8 Tov, Scribal Practices, 249-260.

9 The only older essay of which I am aware is B.Z. Wacholder, "The Ancient JudaeoAramaic Literature (500-165 BCE): A Classification of Pre-Qumranic Texts", in Archaeology and History in the Dead Sea Scrolls: The New York University Conference in Memory of Yigael Yadin (ed. L.H. Schiffman; Sheffield: JSOT Press, 1990), 257-282, which has remained largely ignored.

${ }^{10}$ D. Dimant, "The Qumran Aramaic Texts and the Qumran Community", in Flores Florentino. Dead Sea Scrolls and Other Early Jewish Studies in Honour of Florentino García Martínez (eds. A. Hilhorst, E. Puech, and E. Tigchelaar; Leiden: Brill, 2007), 197205.
} 
the same volume Eibert Tigchelaar published another pioneering article titled "The Imaginal Context and the Visionary of the Aramaic New Jerusalem". ${ }^{11}$

Dimant's article thematically classifies the corpus of Aramaic writings found at Qumran into six categories: 1) Works about the Period of the Flood, 2) Works dealing with the History of the Patriarchs, 3) Visionary Compositions, 4) Legendary Narratives and Court-Tales, 5) Astronomy and Magic, and 6) the inevitable Varia.

Dimant's classification is evidently a 'thematic' classification, and, as such, is not without problems. For example, she is forced to split a composition in two (the Genesis Apocryphon [1QapGen, 1Q20, 6Q19]), because it deals both with the Period of the Flood and with the History of the Patriarchs; ${ }^{12}$ although she recognizes that some compositions (Pseudo Daniel [4Q243-245], Four Kingdoms [4Q552-553], and Apocryphon of Daniel [4Q246]) are 'Court-Tales' like the book of Daniel on which they are dependent, she places them in the category of 'Visionary Compositions'; however, clearly 'visionary' compositions like 1 Enoch (4Q201212), Aramaic Levi (4Q213-214), or Visions of Amram (4Q543-549) are not included in this category; and I think that Emile Puech (the Discoveries in the Judaean Desert-editor of both the Birth of Noah [4Q534-536] and the Apocryphon of Levi (?) [4Q540-541]) would place these compositions in the category of the 'Period of the Flood' and the 'History of the Patriarchs', respectively, because of the protagonists' identification with Noah and Levi, which Dimant rejects as unproved.

These problems are less accentuated in the thematic classification proposed in the article by Eibert Tigchelaar. His contribution represents an initial endeavour to specify the 'imaginal world' (after Henry Corbin) of one of Devorah Dimant's 'Visionary Compositions': the New Jerusalem (1Q32, 2Q24, 4Q554-555, 5Q15, 11Q18). Tigchelaar does not pretend to give us a taxonomy of the Aramaic texts, like Dimant does, but tries to

assess all the textual and contextual clues that might shed light on the identity of the seer

${ }^{11}$ E. Tigchelaar, "The Imaginal Context and the Visionary of the Aramaic New Jerusalem", in Flores Florentino, 257-270.

12 The recently published French bilingual edition of the work has decided to use precisely this title, 'Histoire des Patriarches', to designate the composition, see K. Berthelot, T. Legrand, A. Paul (eds.), La Bibliothèque de Qumrân. 1: Torah, Genèse: Edition bilingue des manuscrits (Paris: Cerf, 2008), 319-387. 
of New Jerusalem (who may be Jacob), and - what is more importantto determine

whether the identity of the seer in a visionary or apocalyptic text is tangential or essential to the imaginal world of the author(s) of the text.

In an aside, Tigchelaar notes that

the Aramaic texts from Qumran only comprise special categories

and that

[t]he vast majority of the Aramaic narrative texts found among the Dead Sea Scrolls belong to two main categories, ${ }^{13}$

namely 1) texts related or ascribed to pre-Mosaic figures, and 2) texts that have an Eastern Diaspora setting, since, with the exception of Daniel, who belongs to a Diaspora setting,

it is remarkable that none of the biblical figures from Moses onwards, through David, and up to the prophets, is connected with Aramaic literature. $^{14}$

Tigchelaar recognizes that a few Aramaic narrative texts do not fit neatly in either of those two categories, but he thinks that this 'dual' division may be useful for dealing with the Aramaic corpus and uses it to identify with slightly more confidence ('as probable') the seer of New Jerusalem not with Ezekiel, as proposed by some scholars, but with Jacob, a preMosaic patriarch. ${ }^{15}$

What is important here, beyond the differences, is that both authors agree fundamentally in their basic approach, since Dimant also recognizes the 'pre-Mosaic' character of the Aramaic literature as well as the Diaspora context:

$[\mathrm{N}] \mathrm{o}$ Aramaic work deals systematically and in detail with Moses and Joshua, the period of the Judges, or the kingdoms of Judah and Israel. For that matter, nothing in Aramaic is related to the biblical Prophets. Obviously, in the understanding of the authors of these texts, Hebrew belonged to the sphere of Israelite history proper, whereas Aramaic is relegated to earlier generations. ${ }^{16}$

And also for Dimant

13 Tigchelaar, "Imaginal Context", 261.

14 Tigchelaar, "Imaginal Context", 261.

15 Tigchelaar, "Imaginal Context", 268.

16 Dimant, "Qumran Aramaic Texts", 203. 
some of the works are set in a Diaspora context, (...). Aramaic was apparently selected as the language of composition precisely because of such a setting, as it was for Dan[iel] $2 .{ }^{17}$

This agreement allows us to answer, albeit tentatively, the question of the Aramaic texts' specificity compared both with other Aramaic compositions and with the Hebrew literature found at Qumran. Although we do have at Qumran some Hebrew compositions which deal with 'pre-Mosaic' protagonists (4QCommentary on Genesis [4Q252-254], for example), and outside Qumran we also have some Aramaic works with a Diaspora setting (Ahiqar, for example), we can assert that the Aramaic literature found at Qumran is characterized by a predominant interest in 'pre-Mosaic' protagonists or by a setting in the Diaspora. Dimant's conclusion:

[b] ut the data already at hand demonstrates the need to consider these texts as a specific group, which requires further detailed investigation along these lines ${ }^{18}$

can therefore be subscribed to without reservations.

A careful look at the compositions classified by Dimant allows, in my opinion, the discovery of another element of the Aramaic texts' specificity, namely the apocalyptic character of a disproportionately large number of these compositions when compared both with the rest of the known compositions in Aramaic and with the Hebrew compositions found at Qumran (sectarian or not).

Dimant describes her 'Visionary Compositions' as 'a complex of Aramaic visionary apocalyptic tales' (my emphasis) and notes that

[t]hese texts describe visionary scenes, often dealing with figures and events of the eschaton. ${ }^{19}$

If we take seriously the adjective 'apocalyptic' that Dimant uses in her description and draw up a list of the Aramaic compositions based on apocalypticism, we can sensibly increase the number of compositions which could be ranked in this category of 'Visionary Compositions' in addition to those Dimant placed in the third category (the New Jerusalem, the Four Kingdoms [4Q552-553], the so-called Apocryphon of Daniel [4Q246], the Words of Michael [4Q529], the so-called Birth of Noah [4Q534-536], the so-called Apocryphon of Levi (?) [4Q540-541,

17 Dimant, "Qumran Aramaic Texts", 204.

18 Dimant, "Qumran Aramaic Texts", 205.

19 Dimant, "Qumran Aramaic Texts", 203. 
5Q15(?)], and Pseudo Daniel [4Q243-245]). 1 Enoch [4Q201-212], and the Book of Giants [1Q23-24, 2Q6, 4Q530-533, 6Q8], of course, will have a place of pride, but also the Visions of Amram (4Q543-549) and other testamentary compositions, like Testament of Jacob (?) (4Q537), and many other fragmentarily preserved compositions can be included.

I am not claiming that these Aramaic compositions all form Qumran apocalypses according to the definition laid down in the journal Semeia 14 (1979) - although several of them definitely do-but the apocalyptic outlook of all these compositions seems clear to me. ${ }^{20}$ Also, I am not pretending that apocalypticism is absent from the Hebrew compositions (sectarian or not) found at Qumran (it is enough to think of the War Scroll [1QM; 4Q491-497] and related texts for the first category or of the Pseudo Ezekiel [4Q385-388] for the second). I claim only that a disproportionately large amount of these Aramaic compositions show an apocalyptic outlook, and that this (if we are not afraid of apocalypticism) allows us to conclude that a predominant interest in apocalypticism also characterizes the Aramaic texts found at Qumran (although we cannot find it, of course, in all Aramaic compositions). In my opinion, this characteristic may help us to answer the third question, concerning their function within the collection. ${ }^{21}$ But before we move to this point, we need to deal with the second one: the possible Qumran origins of the Aramaic compositions.

${ }^{20}$ J.J. Collins, "Apocalypticism and Literary Genre in the Dead Sea Scrolls", in The Dead Sea Scrolls after Fifty Years: A Comprehensive Assessment, vol. 2 (eds. P.W. Flint and J.C. VanderKam; Leiden: Brill, 1999), 403-430.

${ }^{21}$ In his contribution to the Groningen meeting of April 2008, Eibert Tigchelaar insisted that the Aramaic texts from Qumran were not only apocalyptic in outlook, but that they could also be characterized as different from the Hebrew texts because the Aramaic compositions were mainly narrative in character, and because they explicitly state the way in which revelation is imparted (be it by dreams, visions, otherworldly traveling or angelic intermediaries). This clearly opens a whole series of questions on the literary conventions used by the texts in question and their concrete origins. See E. Tigchelaar, "Aramaic Texts from Qumran and the Authoritativeness of Hebrew Scripture", in The Authoritativeness of Scripture in Ancient Judaism (ed. M. Popović; Leiden: Brill, forthcoming). These questions should also be dealt with in a comprehensive study of the characteristics of the Aramaic texts from Qumran. But for my purpose here, the apocalypticism of most of these compositions is the key characteristic which will allow us to answer the question of their function within the whole collection of manuscripts. 


\section{Possible Qumran Origins}

Dimant (like many other illustrious defenders of the same position, such as Stanislav Seger ${ }^{22}$ and Ben Zion Wacholder ${ }^{23}$ assumes that

the Aramaic texts contain nothing of the specifically sectarian terminology or ideology, and therefore do not belong with the sectarian literature. ${ }^{24}$

But I refuse to accept this a priori. The simple fact that a composition is written in Aramaic does not exclude the possibility of its having been written by the people who collected the works that now form the collection of Qumran. There are too many indications or linguistic pluralities in the collection that need to be disregarded in order to sustain this position. Among them, the presence of Aramaic in the documentary texts and the influence of Aramaic in the Hebrew of the documentary texts, which points to the bilingualism of the writers; ${ }^{25}$ the influence of Aramaic in the original literary compositions written in Hebrew $^{26}$ and the influence of Hebrew in many of the Aramaic compositions; ${ }^{27}$ the fact that from an Aramaic composition like Tobit we have found together with the Aramaic manuscripts (4Q196-199) a Hebrew copy (4Q200), and that from books like Job or Leviticus Aramaic translations have been found in the collection (4Q156-157, 11Q10); and even the reference of Milik to 4Q232 as an assumed Hebrew copy of the New Jerusalem (although I was not able to identify the remains of $4 \mathrm{Q} 232$ in the fragments reproduced on PAM $43.368,{ }^{28}$ I cannot exclude that this tiny fragment will show up, as

${ }^{22}$ S. Segert, "Bedeutung der Handschriftenfunde am Toten Meer für die Aramäistik", in Bibel und Qumran (ed. S. Wagner; Berlin: Evangelische Haupt-Bibelgesellschaft, 1968), 183-187 (184): 'Ebenso wie diese Texte, die sprachlich zu den biblisch-aramäischen gehören, entstammen die anderen in den Qumranhöhlen gefundenen aramäischen Handschriften anscheinend nicht der schriftstellerischen Tätigkeit der Essänergemeinde, die einst ihr Zentrum in dem jetzt Chirbet Qumran genannten Gebäude hatte.

${ }^{23}$ B.Z. Wacholder, "The Ancient Judaeo-Aramaic Literature", 273: 'In other words, these Aramaic texts were considered to be the ancestral patrimony of the sect itself and received their share of careful study and exegesis'.

${ }^{24}$ Dimant, "The Qumran Aramaic Texts", 198-199.

${ }^{25}$ See G. Wilhelm Nebe, "Die hebräische Sprache der Nahal Hever Dokumente $5 / 6$ Hev 44-46", in The Hebrew of the Dead Sea Scrolls and Ben Sira (eds. T. Muraoka and J.F. Elwolde; Leiden: Brill, 1997), 150-157.

${ }^{26}$ A fact recognized from the beginning and definitively proved by E.Y. Kutscher in The Language and Linguistic Background of the Isaiah Scroll (Jerusalem: Magnes, 1959), 19-22 (Hebrew).

27 See, most recently, C. Stadel, Hebraismen in den aramäischen Texten vom Toten Meer (Heidelberg: Winter, 2008).

${ }^{28}$ F. García Martínez, “The Temple Scroll and the New Jerusalem", in The Dead Sea 
has happened with the Catalogue of Spirits discovered by Tigchelaar), ${ }^{29}$ should be carefully considered. For all these reasons, and simultaneously recognizing that the most characteristic 'sectarian' compositions have been written in Hebrew (implying that Hebrew was the group's preferred language for penning their own compositions), ${ }^{30} \mathrm{I}$ think that the answer to the question of a sectarian or non-sectarian origin of the Aramaic compositions should be put with the same rigor as it is for each Hebrew composition found at Qumran, and not decided a priori.

The identity of the scribal practices and approaches reflected in the texts written in Aramaic and the texts written in Hebrew strongly suggest that the whole collection has the same origin, and the same 'default position' should be held for both sorts of texts: no text (written in Hebrew or in Aramaic) should be considered 'qumranic' or 'sectarian' until positively proved.

Again, I am not claiming for any concrete text written in Aramaic that it has a Qumranic origin. I am only denying the idea that this Qumranic origin is impossible a priori because the text happened to have been written in Aramaic. This is the position apparently assumed by Tov, ${ }^{31}$ since, when recording the data on the presumed Qumran community authorship of the different compositions, he considers the matter 'irrelevant' in the cases of biblical and Aramaic texts:

Scrolls after Fifty Years (see above, n. 20), vol. 2, 431-46o (445-446, n. 27). The fragments found from the Qumran caves were collected, joined, numbered and photographed at the Palestine Archaeological Museum (PAM), now the Rockefeller Museum, Jerusalem.

${ }^{29}$ E.J.C. Tigchelaar, “'These are the Names of the Spirits of ...': A Preliminary Edition of 4 QCatalogue of Spirits (4Q230) and New Manuscript Evidence for the Two Spirits Treatise (4Q257 and 1Q29a)", Revue de Qumran 21/84 (2004): 529-547.

${ }^{30}$ I think this can be accepted without difficulty, and without entering into the problems posed by the hypothesis of Schniedewind who argues that Qumran Hebrew is an 'antilanguage', see W.M. Schniedewind, "Qumran Hebrew as an Antilanguage", Journal of Biblical Literature 118 (1997): 235-252, and "Linguistic Ideology in Qumran Hebrew", in Diggers at the Well (eds. T. Muraoka and J.F. Elwolde; Leiden: Brill, 2000), 245255.

31 Tov, Scribal Practices, 278 (n. 339), following D. Dimant, "The Qumran Manuscripts: Contents and Significance", in Time to Prepare the Way in the Wilderness (eds. D. Dimant and L.H. Schiffman; Leiden: Brill, 1995), 25-58; C.A. Newsom, "Sectually Explicit' Literature from Qumran”, in The Hebrew Bible and Its Interpreters (eds. W.H. Propp, B. Halpern and D.N. Freedman; Winona Lake: Eisenbrauns, 1990), 167-187; A. Lange, "Kriterien essenischer Texte", in Qumrankontrovers: Beiträge zu den Textfunden vom Toten Meer (eds. J. Frey and H. Stegemann; Paderborn: Bonifacius, 2003), 59-69; C. Hempel, "Kriterien zur Bestimmung 'essenischer Verfasserschaft' von Qumrantexten", in Qumrankontrovers, 71-85. 
Sectarian nature: data on the presumed authorship by the Qumran community, recorded as ' $y[\mathrm{es}]$ ', 'n[o]', or '-' (irrelevant in the case of biblical and Aramaic texts). ${ }^{32}$

Tov is well-known for having carefully described what he calls the 'Qumran scribal practice' according to which he recognizes a group of 167 nonbiblical and biblical manuscripts that display distinctive features and have been 'probably written mainly at Qumran'. In Tov's words:

The main argument for our view pertains to the fact that within the Qumran corpus a group of 167 biblical and nonbiblical texts display distinctive features, and that most of them are sectarian. Conversely, virtually all the sectarian texts were written in this special practice. ${ }^{33}$

But again, in the tables of Appendix 1,34 Tov puts the sign of 'irrelevant' in front of the Aramaic texts in the column of 'Qumran scribal practice'.

Tov has singled out eighteen elements as characteristic of the Qumran scribal practice. ${ }^{35}$ A look at the photographs shows that many-in fact most-of these elements are also attested (more or less intensively) in some Aramaic manuscripts:

- Paragraphos signs: 4QLevi ${ }^{\mathrm{b}}$ (4Q213a); 4QQahat ar (4Q542); 4QEnGiants $^{\mathrm{d}}$ (4Q532)

- Cancelation dots: 1QapGen; 4QEnastr ${ }^{\mathrm{a}}$ (4Q208); 4QEnGiants ${ }^{\mathrm{d}}$ (4Q532)

- Crossing out of letters with a line: $4 \mathrm{QLevi}^{\mathrm{b}}$ (4Q213a); $4 \mathrm{QEnGiants}{ }^{\mathrm{b}}$ (4Q530); 4QEnGiants ${ }^{\mathrm{e}}$ (4Q533)

- Parenthesis signs: 4QpapTob ${ }^{\mathrm{a}}$ (4Q196); 4QEn ${ }^{\mathrm{a}}$ (4Q201)

- Writing of Divine Name in Paleo-Hebrew characters: 4QpsDan ${ }^{\mathrm{a}}$ (4Q243)

- Single letters in Cryptic A script: 4QpapTob ${ }^{a}$ (4Q196)

- Tetrapuncta designating the Tetragrammaton: 4QpapTob ${ }^{\mathrm{a}}$ (4Q196)

- Guide dots: 1QNJ (1Q32); 4QEnastr' ${ }^{\mathrm{C}}$ (4Q210); 4QLevi ${ }^{\mathrm{a}}$ (4Q213); 4QLevi ${ }^{\mathrm{b}}$ (4Q213a); 4QVisions of Amram $^{\mathrm{d}}$ (4Q546); 4QVisions of Amram $^{\mathrm{e}}$ (4Q547)

I have omitted from this list the two most characteristic and important elements Tov sees as indicators of the Qumran scribal practice, namely orthographic and morphological features. I have left these features out

32 Tov, Scribal Practices, 278.

33 Tov, Scribal Practices, 262.

34 Tov, Scribal Practices, 277-288.

35 Tov, Scribal Practices, 263-364. 
not because they are disputed by other scholars, but because the orthographic and morphological characteristics are specific to Hebrew texts and to Hebrew as a language, and as such cannot be applied to Aramaic texts. Although Tov distinguishes carefully between the 'sectarian nature' of a text, and the Qumran scribal practice, in fact the emphasis given to the orthographic and morphological characteristics that are specific to Hebrew texts and to Hebrew as a language lead him to circular reasoning. Tov strongly defends himself against such an accusation:

No circular reasoning is involved in that determination, since the decision of whether or not to characterize a text as the Qumran scribal practice was based on the aforementioned criteria, and not on contents. ${ }^{36}$

Nevertheless, there has been an a priori decision on language, and this is not without consequences.

If it is true, as Tov says, that the scribal features

provide more objective criteria for analysis than the analysis of orthography and morphology, ${ }^{37}$

we should conclude that a certain number of Aramaic texts have been copied in the same Qumran scribal practice as the other texts described by Tov (many of which are considered rightly as 'qumranic' or 'sectarian'). And I think we should also conclude that the qumranic origin of some Aramaic texts is equally possible, and that this question should be discerned on a case-by-case basis, precisely as it is done with the Hebrew compositions.

\section{Function within the Collection}

I think I can be short (and more assertive) in my answer to the third question, the question of the Aramaic compositions' function within the collection as a whole (particularly those of the third category described by Devorah Dimant as 'Visionary Compositions', or the enlarged category I have suggested of 'apocalyptic writings'), since the question of the function and use is independent of the question of origins. The Aramaic 'apocalyptic' compositions, both those known outside the collection (like 1 Enoch or Daniel) and those only known because they were found there,

\footnotetext{
36 Tov, Scribal Practices, 272.

37 Tov, Scribal Practices, 262.
} 
were read and cherished by the group that formed and preserved the collection, and they have so profoundly shaped the group of Qumran that we can define the Qumran community as an 'apocalyptic community. ${ }^{38}$

In his beautiful contribution to the Groningen symposium of April $2008,{ }^{39}$ George Brooke analyzed the influence of the rewriting of Scripture in the forming of the community, concluding that what is needed is a

matrix of mantic wisdom and the interpretative role of the priest, where the prophetic needs to be juxtaposed with 'parabiblical' and scribal activity.

I think we can apply these words also to the influence of the Aramaic compositions in the Qumran community, independently of their origins, which in most of the cases we will not be able to ascertain.

Nobody really bothers about the origins (for example) of Deuteronomy, or of Isaiah, or of the Psalms (assuming that such origins could be determined), when dealing with the influence of those books on the clearly sectarian writings from Qumran; what counts is the way these books inspired and modelled the thinking of the people who collected the many manuscripts of Deuteronomy, Isaiah or Psalms found there, how these books were rewritten and interpreted by them, how the ideas of these books informed and inspired their own writings, and how they helped them to live their lives. And I think the same can be said of the Aramaic compositions, some present in multiple copies in the collection, because the group to which we owe the collection appropriated the contents of these Aramaic compositions in a way similar to how they appropriated the contents of all other religious literature they preserved. And since apocalypticism is one of the characteristic elements of many of the Aramaic compositions (not to say of the Aramaic compositions as a whole), I think we can assert that the apocalyptic outlook and the apocalyptic world view of the Qumran group was informed by these writings.

These Aramaic compositions were part and parcel of the religious literature of the time. Their presence in the collection from Qumran shows us that this religious literature deeply influenced the thinking of the group (as they deeply influenced the thinking of another group,

${ }^{38}$ F. García Martínez, "Apocalypticism in the Dead Sea Scrolls", in Qumranica minora, vol. 1 (Leiden: Brill, 2007), 195-226.

${ }^{39}$ G.J. Brooke, "The Apocalyptic Community, the Matrix of the Teacher and Rewriting Scripture", in Authoritativeness of Scripture (see above, n. 21), forthcoming. 
Christianity, to which we owe the preservation in translation of several of them). Why later rabbinic Judaism left this Aramaic literature out (which it certainly did not do because it was written in Aramaic), still needs to be explained. But that is another story. 